\title{
Corm and Cormel Production Improvement of Gladiolus by Spacing and Size
}

\author{
N.J. Methela ${ }^{1}$, M.S. Islam ${ }^{1 *}$ \\ ${ }_{1}^{1}$ Department of Agriculture, Noakhali Science and Technology University, Bangladesh
}

\section{ARTICLE INFO}

\section{Article history:}

Received: 17 August 2020

Revised version received: 15 March 2021

Accepted: 02 April 2021

Available online: 01 October 2021

\section{Keywords:}

Corm

Cormel

Gladiolus

Plant spacing

Yield

\section{Citation:}

Methela N.J. and Islam, M.S. (2021). Corm and cormel production improvement of gladiolus by spacing and size. Tropical Agricultural Research, 32(4): 445-452

DOI: http://doi.org/10.4038/tar.v32i4.8409

Methela N.J.

https://orcid.org/0000-0003-4108-3028

\section{ABSTRACT}

Gladiolus is one of the cut flowers in much demand throughout the world due to its spectacular colorful bloom and long shelf life. Corm and cormels are the major propagative units for this plant. However, lower multiplication rate is a great hindrance for commercial production. This experiment was conducted at research plots of the Bangladesh Agricultural University, Mymensingh, Bangladesh during the period of October 2017 to May 2018. The two-factor experiment included plant spacing (S $1=25 \mathrm{~cm} \times 20 \mathrm{~cm}, \mathrm{~S} 2=20 \mathrm{~cm} \times 30 \mathrm{~cm}, \mathrm{~S} 3=25 \mathrm{~cm} \times 30 \mathrm{~cm})$ as factor A and corm size (C1 = Small corm, 30 $\pm 2 \mathrm{~g}$, C2 = Medium corm, 35 $\pm 2 \mathrm{~g}$, C3 = Large corm $40 \mathrm{~g}$ to $65 \mathrm{~g}$ ) as factor B. Hence, nine combinations were set up as treatments with three replicates in a Randomized Complete Block Design (RCBD) to explore improvement of corm and cormel production of gladiolus. Positive responses were found in experimental parameters such as corm diameter, weight of corm and cormels per plant, weight of corm and cormels per plot and yield of corms and cormels with increasing plant density and corm size. Results of the experiment revealed that yield of corms (23.08 t/ha) and yield of cormels (16.12 t/ha) were the highest with the treatment combination S3C3. This investigation concluded with the $g$ reatest corm and cormel production of gladiolus through the combination of wider plant spacing and large corm size under experimental conditions in Bangladesh.

\footnotetext{
${ }^{*}$ Corresponding author: safi.agri21@gmail.com
} 


\section{INTRODUCTION}

Gladiolus (Gladiolus grandifloras L.) is ranked $8^{\text {th }}$ as a commercial and popular cut flower in the world market (Memon et al., 2016). This is a monocotyledonous bulbous plant belonging to the Iridaceae family, also called queen of bulbous flowers (Roy et al., 2017). Gladiolous are grown the most in countries such as the United States (Florida and California), Italy, Holland, France, Poland, Brazil, Bulgaria, India, Australia and Israel (Memon et al., 2016). However, its origin is South Africa. Plants complete their life cycle within 110-120 days at a temperature regime between 10 and $25^{\circ} \mathrm{C}$ (Rashid 2018).

Usually, the commercial propagation materials of bulbous plants are underground storage structures such as bulbs of lilies and corm of gladiolus. Corm is a modified structure of the stem with distinct nodes and internodes. Being a cormous plant, gladiolus is generally propagated through new corms and cormels (Hartman et al., 1990). Corm and cormels are the most important factor that governs the growth and development of gladiolus. Thus, they influence commercial production of the cut flower that is in most demand, gladiolus (Sudhakar and Kumar, 2012). However, inadequate supply of planting material due to lower rate of multiplication is a significant problem in spike and corm production for gladiolus (Singh and Dohare 1994). Normally a new corm along with a few cormels are produced from a mother corm. Cormels need three to four seasons to attain optimum size for using as propagation materials. Division of corms having at least a single bud increases production (Memon et al., 2009). Early elimination of spikes (Singh et al., 1978) and mechanical exclusion of sprouts in succession throughout storage (Sharga and Basario 1976) were reported to enhance corms and cormels production. Physiological dormancy of corms is another obstacle for gladiolus production (Baskaran et al., 2009). External application of plant growth regulators viz. Naphthalene acetic acid (NAA) and gibberellins were found effective for breaking this dormancy along with promoting growth and number of corms (Suresh Kumar et al., 2008, Rashid 2018).

Yield of corms and cormels is greatly influenced by several factors such as cultivar, plant spacing, corm size, nutrition, agro-techniques, plant density etc. of which size of the mother corm and spacing, play an important role (Singh and Bijimol 2003; Mukhopadhyay and Yadav 1984). Optimum spacing helps not only in obtaining good quality cut flowers but also corm and cormel production with better utilization of resources that is vital for successive crop production and quality (Sanjib et al., 2002). Smaller sized corms lead to poor yields whereas larger sized corms produce good yield (Methela et al., 2019). Several researchers have suggested different spacing such as $20 \times 20 \mathrm{~cm}$, $25 \times 20 \mathrm{~cm}, 30 \times 30 \mathrm{~cm}$ (Mukhopadhyay and Yadav 1984, Bhattacharjee 1981, Patil et al., 1995) for improving production of gladiolus. However, their research work is outdated since climatic conditions have changed at present. In addition, corms of larger sizes such as $30 \mathrm{~g}$ and $40 \mathrm{~g}$ produce the maximum yield of corms and cormel (Methela et al., 2019). As the current information is insufficient regarding proper spacing and corm size under present climatic conditions, we conducted this experiment with a view to finding out the optimum size of corms and spacing to obtain best quality corm and cormel production of gladiolus.

\section{METHODOLOGY}

\section{Experimental site and soil}

The current experiment was carried out at research plots of the Bangladesh Agricultural University at Mymensingh, Bangladesh from October 2017 to May 2018. Soil of the experimental site was medium high land belonging to the old Brahmaputra Flood Plain under AEZ-9 having noncalcareous dark gray flood-plain soil (FA0 2012). Texture of the soil was silt loam and $\mathrm{pH}$ was 6.8, land of the experimental site was located at $6.7 \mathrm{~m}$ above sea level. It was well drained with good irrigation facilities.

\section{Climate}

The locality, where the experiment was carried out has three distinct seasons viz. winter or dry season extending from October to January, pre-monsoon period or hot season from February to April and monsoon or rainy season from May to September. Information regarding monthly maximum and minimum temperature, rainfall, relative humidity, soil temperature as recorded by the weather yard of the Department of Irrigation and water Management, Bangladesh Agricultural University at Mymensingh during the period of study have been presented in Table 1.

\section{Planting Materials, Treatment and Design}

Different sizes of corms of gladiolus were used as planting materials, which were collected from Landscape Section, Bangladesh Agricultural University at Mymensingh. The experiment had two factors as $\mathrm{A}$ and B. Factor A was plant spacing $\left(\mathrm{S}_{1}=25 \times 20 \mathrm{~cm}, \mathrm{~S}_{2}=20 \times 30 \mathrm{~cm}, \mathrm{~S}_{3}=25 \times 30 \mathrm{~cm}\right)$ and 
Table 1. Monthly record of temperature, rainfall, relative humidity and average sunshine during the period from October, 2017 to May, 2018

\begin{tabular}{|c|c|c|c|c|c|c|c|}
\hline \multirow{2}{*}{ Year } & \multirow{2}{*}{ Month } & \multicolumn{3}{|c|}{ Air Temperature $\left({ }^{\circ} \mathrm{C}\right)$} & \multirow{2}{*}{$\begin{array}{c}\text { Relative } \\
\text { humidity } \\
\text { (\%) }\end{array}$} & \multirow{2}{*}{$\begin{array}{c}\text { Rainfall } \\
\text { (mm) }\end{array}$} & \multirow{2}{*}{$\begin{array}{c}\text { Sunshine } \\
\text { (hrs) }\end{array}$} \\
\hline & & Maximum & Minimum & Average & & & \\
\hline \multirow[t]{3}{*}{2017} & October & 32.50 & 23.20 & 27.90 & 82.90 & 78.00 & 205.9 \\
\hline & November & 30.00 & 18.10 & 23.40 & 82.20 & 4.30 & 200.00 \\
\hline & December & 25.20 & 13.30 & 19.30 & 83.40 & 0.00 & 117.90 \\
\hline \multirow[t]{5}{*}{2018} & January & 23.90 & 12.01 & 17.99 & 84.68 & 18.20 & 84.70 \\
\hline & February & 28.79 & 16.80 & 22.34 & 80.14 & 8.40 & 137.80 \\
\hline & March & 31.05 & 18.95 & 25.58 & 75.90 & 104.80 & 187.30 \\
\hline & April & 30.00 & 24.30 & 28.40 & 81.20 & 53.00 & 171.20 \\
\hline & May & 30.95 & 23.73 & 27.90 & 80.00 & 331.10 & 165.30 \\
\hline
\end{tabular}

Table 2. Doses of manure and fertilizers applied for the production of the crop

\begin{tabular}{lcc}
\hline Manures and Fertilizers name & Doses per plot & Doses per hectare \\
\hline Cow dung & $1.5 \mathrm{~kg}$ & $10 \mathrm{ton}$ \\
Urea & $24 \mathrm{~g}$ & $200 \mathrm{~kg}$ \\
Triple superphosphate & $27 \mathrm{~g}$ & $225 \mathrm{~kg}$ \\
Muriate of potash & $22.8 \mathrm{~g}$ & $190 \mathrm{~kg}$ \\
\hline
\end{tabular}

B was corm size $\left(\mathrm{C}_{1}=\right.$ Small corm, $30 \pm 2 \mathrm{~g}, \mathrm{C}_{2}=$ Medium corm, $35 \pm 2 \mathrm{~g}, \mathrm{C}_{3}=$ Large corm $>40 \mathrm{~g}$, not more than $65 \mathrm{~g}$ ). There were a total of 9 treatment combinations, namely, $\mathrm{S}_{1} \mathrm{C}_{1}, \mathrm{~S}_{1} \mathrm{C}_{2}, \mathrm{~S}_{1} \mathrm{C}_{3}, \mathrm{~S}_{2} \mathrm{C}_{1}, \mathrm{~S}_{2} \mathrm{C}_{2}$, $\mathrm{S}_{2} \mathrm{C}_{3}, \mathrm{~S}_{3} \mathrm{C}_{1}, \mathrm{~S}_{3} \mathrm{C}_{2}$ and $\mathrm{S}_{3} \mathrm{C}_{3}$ in this experiment. The investigation was laid out in a Randomized Complete Block Design (RCBD) with three replicates. Each block was divided into nine plots where treatments were allotted randomly. Thus, there were $27(9 \times 3)$ unit plots in the experiment. The size of a unit plot was $1 \mathrm{~m} \times 1.2 \mathrm{~m}$. Distance between blocks was $50 \mathrm{~cm}$ and $25 \mathrm{~cm}$ between adjacent plots.

\section{Land Preparation}

The plot was well prepared with several ploughings and cross ploughing with a power tiller followed by laddering to obtain a good tilth. Weeds and inert materials were removed before final land preparation. Table 2 shows basal doses of manures (well decomposed cow dung) and recommended doses of fertilizers applied during final land preparation (BARC, 2012).

\section{Corm Treatment and planting}

Corms were soaked in $0.1 \%$ Bavistin solution for five minutes and then air dried to avoid rotting in the field and planted at a depth of $6 \mathrm{~cm}$ in furrows.

\section{Intercultural operations}

Continuous weeding was performed during the whole life cycle. Mulching was done after each irrigation by breaking the upper crust for easy aeration and to conserve soil moisture. Irrigation was done twice during the whole period of plant growth. Earthing up was an effective practice for better corm production. The first and second earthing up were done at 25 and 50 days after planting.

\section{Disease and Pest Management}

Plants were infested by botrytis leaf spot and blight disease during early growing stage. The disease was controlled by spraying Dithane ${ }^{\circledR} M-45$, twice at 15 days interval. The crop was also attacked by aphids during the early growing stage. Aphids were controlled by spraying Aksis ${ }^{\circledR} 20 \mathrm{EC}$ thrice at 7 days interval.

\section{Harvesting and Data Record}

Materials for propagation of gladiolus, i.e. corms and cormel, were harvested during the last week of May 2018, when $25 \%$ of cormels had become brown and the leaves also started yellowing. Data were recorded on Diameter of corm (cm), weight of corm per plant $(\mathrm{g})$, weight of corm per plot $(\mathrm{kg})$, weight of cormels per plant (g), weight of cormels 
per plot $(\mathrm{kg})$, yield of corms (t/ha) and yield of cormels ( $\mathrm{t} / \mathrm{ha})$.

\section{Statistical analysis}

Collected data were statistically analyzed using MSTAT-C computer package program. Means for all treatments was calculated and the analysis of variance (ANOVA) for each of the characters was performed by $\mathrm{F}$ test. Differences between treatment means were evaluated by least significant difference (LSD) test at $\mathrm{P}=0.01$ or $\mathrm{P}=0.05$, where applicable (Gomez and Gomez, 1984)

\section{RESULTS AND DISCUSSION}

\section{Diameter of corm}

Treatment combination of plant spacing and corm size was found to be significant in respect of diameter of corm (Table 3 ). The maximum and minimum diameter of corm $(7.1 \mathrm{~cm}$ and $5.6 \mathrm{~cm}$, respectively) were obtained from treatment combinations of wider plant spacing $25 \mathrm{~cm} \times 30 \mathrm{~cm}$ with large corm size ( $65 \mathrm{~g}$ ) and less spacing $25 \mathrm{~cm}$ x $20 \mathrm{~cm}$ with lower corm size, respectively (Table 3). Larger spacing and corm size help improving diameter of corms. Results of this experiment were similar to those reported by Bhat and Khan (2007) and Sudhakar and Kumar (2012), that the variation of corm diameter is due to excessive growth of the plant and translocation of more photosynthetic products toward the corm. Availability of more food material stored in large sized mother corms has helped in better corm and cormel production. Additionally, a wider spacing ensures more area for better root growth and nutrient absorption along with accessibility of more light for higher rate of photosynthesis. As a result, translocation of photosynthates to storage organ is increased.

\section{Weight of corm and cormels per plant}

Table 3 shows significant variation in weight of corms and cormels depending on plant spacing and corm size. The highest corm weight per plant (115.4 g) was recorded when the corms of the largest size ( $>40 \mathrm{~g}$ ) planted at a spacing of $25 \mathrm{~cm} \mathrm{x}$ $30 \mathrm{~cm}$, while the lowest (88.67 g) was recorded in plots planted to the smallest corm size $(30 \pm 2 \mathrm{~g})$ at spacing of $25 \mathrm{~cm} \times 20 \mathrm{~cm}$ (Table 3). The results observed in the case of cormel production showed a similar trend. Kumar et al. (2016), while reporting similar results, explained that the response was due to the absorption of nutrient and moisture and no shading effect, which ultimately increases rate of net photosynthates and translocation of assimilates to the storage organ. Bhat and Khan (2007) reported that larger sized mother corms have positively influenced the weight of 10 corms (480.55 g) and cormels (35.55 g) per plant. Additionally, the widest plant spacing $(20 \mathrm{~cm} \times 20 \mathrm{~cm})$ significantly increased the weight

Table 3. Corm and cormel production of gladiolus by the combination of spacing and corm size

\begin{tabular}{|c|c|c|c|c|c|}
\hline $\begin{array}{l}\text { Treatment of } \\
\text { combination }\end{array}$ & $\begin{array}{c}\text { Diameter of } \\
\text { corm } \\
(\mathbf{c m})\end{array}$ & $\begin{array}{l}\text { Weight of } \\
\text { corm/plant } \\
\text { (g) }\end{array}$ & $\begin{array}{c}\text { Weight of } \\
\text { corm/ plot } \\
\text { (kg) }\end{array}$ & $\begin{array}{l}\text { Weight of } \\
\text { cormels/ } \\
\text { plant (g) }\end{array}$ & $\begin{array}{c}\text { Weight of } \\
\text { cormels/ plot } \\
\text { (kg) }\end{array}$ \\
\hline $\mathrm{S}_{1} \mathrm{C}_{1}$ & 5.60 & 88.67 & 2.13 & 60.60 & 1.45 \\
\hline $\mathrm{S}_{1} \mathrm{C}_{2}$ & 5.92 & 95.75 & 2.30 & 63.80 & 1.53 \\
\hline $\mathrm{S}_{1} \mathrm{C}_{3}$ & 6.10 & 98.33 & 2.36 & 68.79 & 1.65 \\
\hline $\mathrm{S}_{2} \mathrm{C}_{1}$ & 5.91 & 95.67 & 2.30 & 65.33 & 1.57 \\
\hline $\mathrm{S}_{2} \mathrm{C}_{2}$ & 6.40 & 100.67 & 2.42 & 70.62 & 1.69 \\
\hline $\mathrm{S}_{2} \mathrm{C}_{3}$ & 6.67 & 104.80 & 2.52 & 78.19 & 1.88 \\
\hline $\mathrm{S}_{3} \mathrm{C}_{3}$ & 6.15 & 108.75 & 2.61 & 70.50 & 1.69 \\
\hline $\mathrm{S}_{3} \mathrm{C}_{2}$ & 6.78 & 110.60 & 2.65 & 75.30 & 1.81 \\
\hline $\mathrm{S}_{3} \mathrm{C}_{3}$ & 7.10 & 115.40 & 2.77 & 80.60 & 1.93 \\
\hline $\mathrm{LSD}_{0.05}$ & 0.155 & 1.543 & 0.055 & 0.751 & 0.017 \\
\hline $\mathrm{LSD}_{0.01}$ & 0.213 & 2.127 & 0.075 & 1.034 & 0.024 \\
\hline $\begin{array}{c}\text { Level of } \\
\text { significance }\end{array}$ & $* *$ & $* *$ & $*$ & $* *$ & $* *$ \\
\hline
\end{tabular}


of 10 corms (465.42 g) and cormels (34.38 g) per plant. Memon et al. (2016) also suggested that jumbo-sized $(>5.1 \mathrm{~cm})$ mother corms increased the weight of corm and cormels produced in gladiolus compared to medium and small-sized mother corm.

\section{Weight of corm and cormels per plot}

The combined effect of plant spacing and corm size was statistically significant $(\mathrm{P}<0.05)$ on the weight of corm and cormels per plot (Table 3 ). The best corm weight per plot $(2.77 \mathrm{~kg})$ was recorded from plant spacing $25 \mathrm{~cm} \times 30 \mathrm{~cm}$ using the largest corm size $(>40 \mathrm{~g})$ while the lowest $(2.13 \mathrm{~kg})$ was recorded when the smallest corm size $(30 \pm 2 \mathrm{~g})$ was planted at $25 \mathrm{~cm} \times 20 \mathrm{~cm}$ (Table 3). Similar results were reported in the case of cormels, too. (Table 3). Farid et al. (2002) stated similar findings. They found that weight of corm and cormels were maximum from larger mother corm (15 g) over 10 $\mathrm{g}, 5 \mathrm{~g}$ and $3 \mathrm{~g}$ mother corm. Kumar et al. (2002) and Suresh et al. (2008) reported that assimilates were transported to these organs increasing their weight, size and volume.

\section{Yield of corms and cormels}

Figures 1and 2 illustrate a significant difference observed with the combined effect of plant spacing and corm size and their interaction on corm and cormels yield per hectare. The highest corm yield $(23.1 \mathrm{t} / \mathrm{ha}$ ) was reported from the combination of the largest corm size $(>40 \mathrm{~g})$ planted at a spacing of $25 \mathrm{~cm} \times 30 \mathrm{~cm}$ and, while the lowest $(17.73 \mathrm{t} / \mathrm{ha})$ was from smallest corm size $(30 \pm 2 \mathrm{~g})$ planted at a spacing of $25 \mathrm{~cm} \times 20 \mathrm{~cm}$ (Figure 1). Similar pattern of results was observed for cormel production as well (Figure 2). McKay et al. (1981) reported that larger corm sizes showed higher yields of new corm and cormels as compared to the smaller-sizes corms. Yield attributes associated to corms and cormels significantly improved with the application of growth regulators in all concentrations when compared to the non-treated control (Sudhakar and Kumar 2012). The availability of more light for photosynthesis as well as more area for better root growth and nutrient absorption with a wider spacing may have contributed to the production of larger corms (Mukhapadhaya and Yadav 1984). Misra (1994) reported that corms as planting material of uniform size ( $40 \mathrm{~g}$ ) yielded superior a corm weight of $64.1 \mathrm{~g}$ in gladiolus

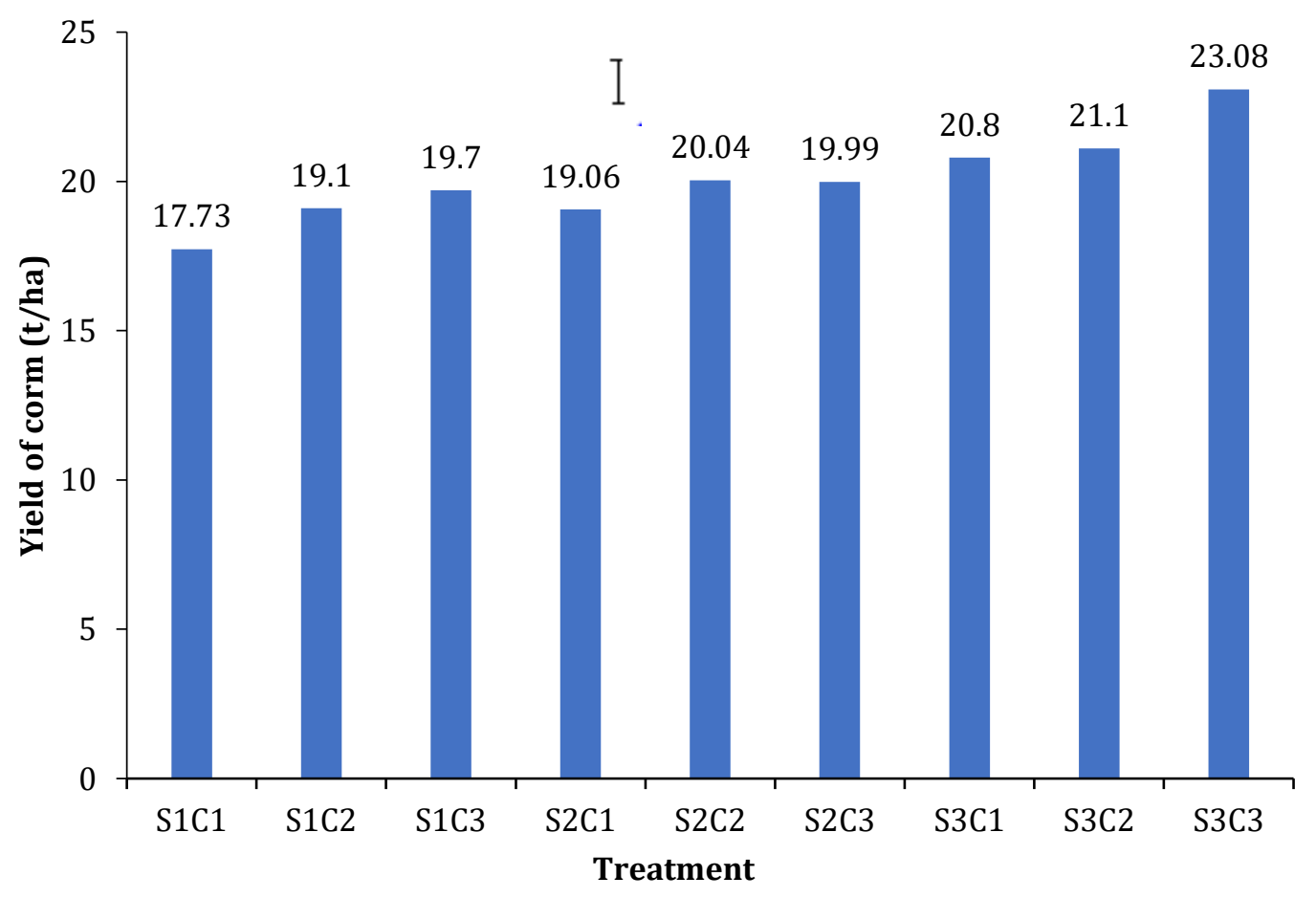

Figure 1. The combined effect of plant spacing and corm size on yield of corms of gladiolus. Vertical line represents LSD at $P=0.01$. $S_{1}=25 \mathrm{~cm} \times 20 \mathrm{~cm}, S_{2}=20 \mathrm{~cm} \times 30 \mathrm{~cm}, S_{3}=25 \mathrm{~cm} \times 30 \mathrm{~cm}$ and $C_{1}=$ Small corm $30 \pm 2 \mathrm{~g}, \mathrm{C}_{2}=$ Medium corm $35 \pm 2 \mathrm{~g}, \mathrm{C}_{3}=$ Large corm $40 \mathrm{~g}$ to $65 \mathrm{~g}$. 


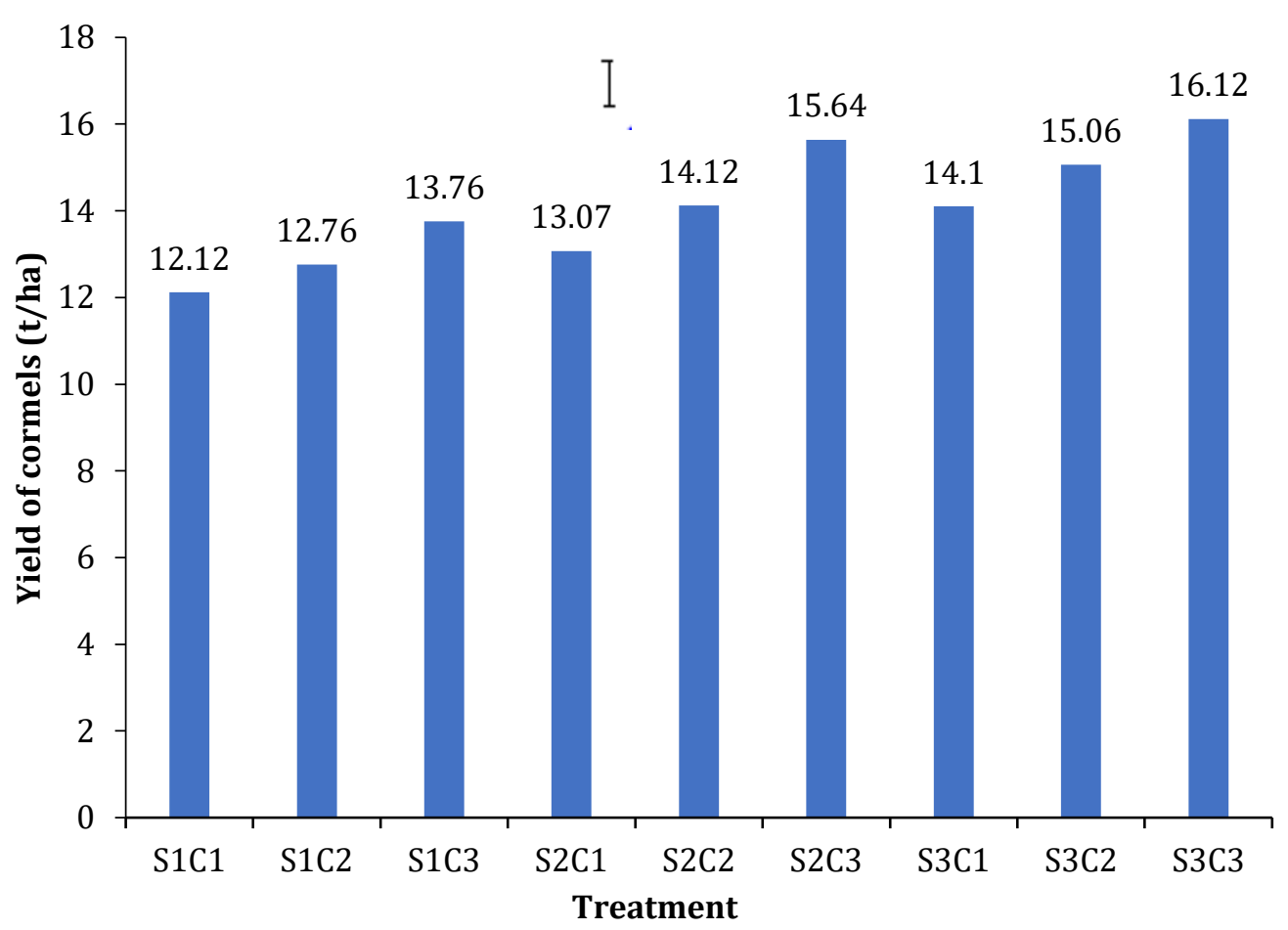

Figure 2. The combined effect of plant spacing and corm size on yield of cormels of gladiolus. Vertical line represents LSD at $\mathrm{P}=0.01 . \mathrm{S}_{1}=25 \mathrm{~cm} \times 20 \mathrm{~cm}, \mathrm{~S}_{2}=20 \mathrm{~cm} \times 30 \mathrm{~cm}, \mathrm{~S}_{3}=25 \mathrm{~cm} \times 30 \mathrm{~cm}$ and $\mathrm{C}_{1}=$ Small corm $30 \pm 2 \mathrm{~g}, \mathrm{C}_{2}=$ Medium corm $35 \pm 2 \mathrm{~g}, \mathrm{C}_{3}=$ Large corm $40 \mathrm{~g}$ to $65 \mathrm{~g}$.

\section{CONCLUSIONS}

The application of different combinations of come size and plant spacing showed a significant response of corm and cormel production of gladiolus. Large-sized corm ( $>40 \mathrm{~g})$ planted at wider spacing $(25 \mathrm{~cm} \times 30 \mathrm{~cm})$ resulted in positive outcomes for diameter of corm, weight of corm and cormels per plant, weight of corm and cormels per plot, yield of cormels and yield of corms. The study concluded that large-sized corms planted at a

\section{REFERENCES}

Baskaran V., Misra R.L. and Abirami K. (2009). Effect of plant growth regulators on corm production in gladiolus. Journal of Horticultural Science, 4(1), 78-80.

BARC (2012). Fertilizer Recommendation Guide. Bangladesh Agricultural Research Council, Farmgate, Dhaka, p.111.

Bhat, Z.A. and Khan, F.U. (2007). Effect of spacing and corm size on growth, flowering and corm wider spacing will effectively increase corm and cormel production of gladiolus.

\section{ACKNOWLEDGMENT}

The authors would like to convey their heartfelt gratitude to the Landscape Section, Bangladesh Agricultural University, Mymensingh in Bangladesh for supplying the quality planting materials of gladiolus.

production in gladiolus cv. White prosperity under Kashmir conditions. Journal of Horticultural Sciences, 2, 112-114.

Bhattacharjee, K.K. (1981). Flowering and corm production of gladiolus as influenced by corm size, planting depth and spacing. Singapore Journal Primary Industries, 9, 18-22.

FAO (2012). Food and Agriculture Organization of the United Nations. Soil Survey Project of Bangladesh. Soil Resources Technical Report, 10, 91-94. 
Farid, U.M, Rahman, M.M., Rabbani, M.G. and Mannan, M.A. (2002). Effect of corm size and depth of planting on the growth and flowering of gladiolus. Pakistan Journal of Biological Science, 5, 553-555.

Gomez, K.A. and Gomez, A.A. (1984). Statistical Procedure for Agricultural Research (2nd ed.). A Willey International Science Publication, John Willey and Sons, New York, pp. 680.

Hartman, H.T., Kester, D.E. and Davies, F.T. (1990). Plant Propagation: Principles and Practices. Englewood Cliffs, New Jersey, Prentice-hall, pp. 647.

Hong, Y.P., Goo, D.H. and Huk, K.Y. (1989). Studies on corm formation in Gladiolus grandavensis: the effects of planting date of cormels on corm production, dormancy and flowering of the corm in the next generation. Research Report Rural Development Administration Horticulture, 31, 54-59.

Khan, F.N., Rahman, M.M., Hossain, M.M. and Hossain, T. (2011). Effect of benzyladenine and gibberellic acid on dormancy breaking and growth of gladiolus cormels. Thailand Journal of Agricultural Science, 44,165-174

Kumar, R., Dubey, R.K. and Misra, R.L. (2002). Effect of $\mathrm{GA}_{3}$ on growth, flowering and corm production of gladiolus. In: Floriculture Research Trend in India, Misra R.L., Sanyat Misra, (Eds.). ISOH, New Delhi, India, pp. 110113.

Kumar, K., Singh, C.N., Beniwal, V.S. and Pinder, R. (2016). Effect of spacing on growth, flowering and corm production of gladiolus (Gladiolus sp.) cv. American Beauty. International Journal of Environment, Agriculture and Biotechnology, 1, 550-554.

McKay, M.E., Byth, D.E.and Tommerup, J. (1981). The effect of corm size and division of the mother corm in gladioli. Australian Journal of Experimental Agriculture and Animal Husbandry, 21, 343-348.

Memon, N., Qasim, M., Jaskani, M.J.and Ahmad, R. (2009). Enhancement of corm and cormel production in gladiolus (Gladiolus spp.). New Zealand Journal of Crop and Horticultural Science, 37, 319-325.

Memon, N.U.N., Wahocho, N.A., Miano, T.F. and Leghari, M.H. (2016). Propagation of gladiolus corms and cormels. a review. African Journal of Biotechnology, 15(32), 1699-1710.

Methela, N.J., Zihad, M.R.A., Islam, M.S. and Rahman M.H. (2019). Effect of spacing and corm size on growth and spike production of gladiolus. Asian Journal of Medical and Biological Research, 5(3), 226-230.

Misra, R.L. (1994). effect of leaf and spike clippings on corm and cormel yield of gladiolus. In Prakash, J. - Bhandary, K.R. ed. FloricultureTechnology, Trades and Trends. India, Oxford \& IBH Publishing Company, pp. 55-58.

Mukhopadhyay, T.K. and Yadav, L.P.(1984). Effect of corms size and spacing on growth, flowering and corm production in gladiolus. Haryana Journal of Horticultural Science, 13, 95-99.

Noor-ul-Amin, Khattak A.M., Ahmad I., Ara N., Alam A., Ali M. and Ali I. (2013). Corm and cormel size of gladiolus greatly influenced growth and development of subsequent corm production. Pakistan Journal of Botany, 4,1407-1409.

Patil, S.S.D., Kalwate, S.M. and Patil, M.T. (1995). Effect of different spacing and corm size and corm size on the flower and corm production of gladiolus. Journal of Mahr. Agriculture University, 20, 122-123.

Rashid, M.H.A. (2018). Influence of size and plant growth regulators on corm and cormel production of gladiolus (Gladiolus grandiflorus L.). Progressive Agriculture, 29(2), 91-98.

Roy, S., Fatmi, U., Kumar, S., Mishra, S.K. and Singh, R.(2017). Effect of pre plant soaking of corms in growth regulators on sprouting, vegetative growth and corm formation in gladiolus (Gladiolus grandiflorus L.). Journal of Pharmacognosy and Phytochemistry, 6(5), 1135-1138.

Sanjib, S., Talukdar, M.C., Sharma, S., Misra, R.L. and Sanyat, M. (2002). Effect of time, spacing, and depth of planting on gladiolus. Floriculture Research Trend India, 7, 243-245.

Sharga, A.N. and Basario, K.K. (1976). Studies on the effect of mechanical removal of gladiolus sprouts on corm and flower production. Bulletin of the North American Gladiolus Council, 127, 15-17.

Singh, A.K. and Bijimol, G. (2003). Effect of spacing and nitrogen on gladiolus. Journal of Ornamental Horticulture, 6, 73-75. 
Singh, R.P., Basario, K.K. and Sharga, A.N. (1978). The effect of variant clipping of spikes on corm production in gladiolus. Bulletin of the North American Gladiolus Council, 133, 57-59.

Singh, A.P. and Dohare, S.R. (1994). Maximisation of corm and cormel production in gladiolus. In: Prakash, J. Bhandary, K.R. ed. FloricultureTechnology, Trades and Trends. India, Oxford \& IBh Pubishing Company. pp. 205-208.
Sudhakar, M. and Kumar, S.R. (2012). Effect of growth regulators on growth, flowering and corm production of gladiolus (Gladiolus grandiflorus L.) cV. white friendship. Indian Journal of Plant Science, 1(2-3), 133-136.

Suresh, K.P., Bhagawat, R., Rajiv, K. and Ronya, T. (2008). Effect of plant growth regulators on vegetative growth, flowering and corm production of gladiolus in Arunachal Pradesh. Journal of Ornamental Horticulture, 11(4), 265270 . 